Canyon Dissolution of Sand, Slag, and Crucible Residues

\author{
John H. Gray \\ David G. Karraker \\ Tracy S. Rudisill \\ Gregory T. Chandler
}

December 1997

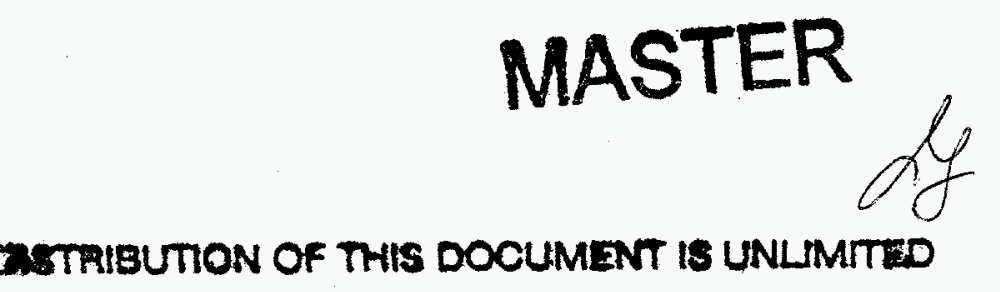

Westinghouse Savannah River Company Building 773-A

Aiken, SC 29808

Prepared for the U. S. Department of Energy under Contract DE-AC09-96SR18500 
Canyon Dissolution of Sand, Slag, and Crucible Residues (U)

By

John H. Gray

David G. Karraker

Tracy S. Rudisill

Gregory T. Chandler

Issued: December 1997

Technical Reviewers

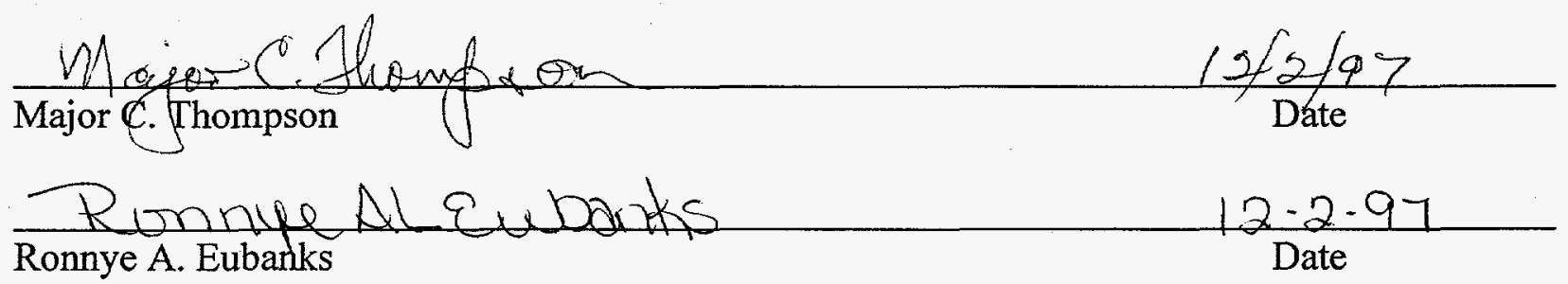

\section{UNCLASSIFIED}

DOES NOT CONTAIN

UNCLASSIFIED CONTAOLLED

NUCLEAR INFORMATIOH

$A D C$ \&

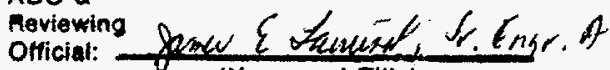

Officiat: (Name and Titto)

Date:

$12-3 \cdot 47$ 


\section{DISCLAIMER}

This report was prepared as an account of work sponsored by an agency of the United States Government. Neither the United States Government nor any agency thereof, nor any of their employees, make any warranty, express or implied, or assumes any legal liability or responsibility for the accuracy, completeness, or usefulness of any information, apparatus, product, or process disclosed, or represents that its use would not infringe privately owned rights. Reference herein to any specific commercial product, process, or service by trade name, trademark, manufacturer, or otherwise does not necessarily constitute or imply its endorsement, recommendation, or favoring by the United States Government or any agency thereof. The views and opinions of authors expressed herein do not necessar. ily state or reflect those of the United States Government or any agency thereof. 


\section{DISCLAIMER}

Portions of this document may be illegible electronic image products. Images are produced from the best available original document. 


\section{Table of Contents}

\section{Section}

Page

Summary

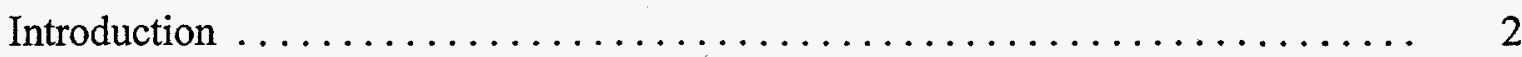

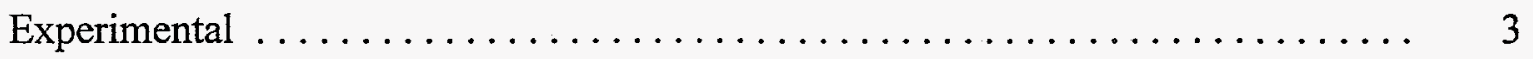

Dissolution Studies $\ldots \ldots \ldots \ldots \ldots \ldots \ldots \ldots \ldots \ldots \ldots \ldots \ldots \ldots$

Hydrogen Generation $\ldots \ldots \ldots \ldots \ldots \ldots \ldots \ldots \ldots \ldots \ldots \ldots \ldots$

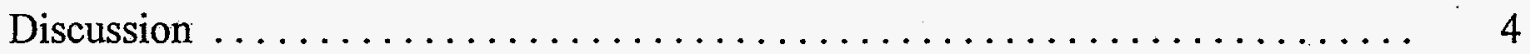

SS\&C Dissolution Flowsheet $\ldots \ldots \ldots \ldots \ldots \ldots \ldots \ldots \ldots \ldots \ldots \ldots \ldots$

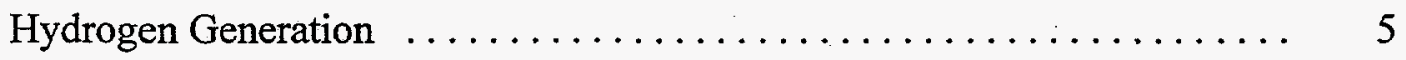

Dissolver Corrosion $\ldots \ldots \ldots \ldots \ldots \ldots \ldots \ldots \ldots \ldots \ldots \ldots$

Conclusions $\ldots \ldots \ldots \ldots \ldots \ldots \ldots \ldots \ldots \ldots \ldots \ldots \ldots \ldots \ldots \ldots \ldots$

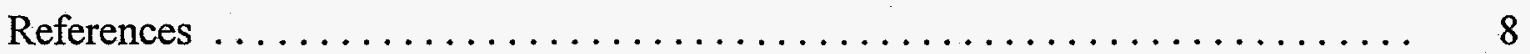

\section{List of Tables}

Table $1 \quad$ Nominal Composition of Sand and Slag Residues . . . . . . . 9

Table 2 Dissolution Times for Sand and Slag Residues $\ldots \ldots \ldots \ldots$

Table 3 Measured Plutonium Concentrations in Sand and Slag Residues $\ldots \quad 11$

Table $4 \quad$ Hydrogen Generation from Sand Fines and Slag Chunks $\ldots \ldots \ldots 12$ 


\title{
Canyon Dissolution of Sand, Slag, and Crucible Residues (U)
}

\author{
John H. Gray \\ David G. Karraker \\ Tracy S. Rudisill \\ Gregory T. Chandler \\ Westinghouse Savannah River Company \\ Savannah River Site \\ Aiken, SC 29808
}

\section{Summary}

An alternative to the FB-Line scrap recovery dissolver was desired for the dissolution of sand, slag, and crucible (SS\&C) residues from the plutonium reduction process due to the potential generation of hydrogen gas concentrations above the lower flammability limit. To address this concern, a flowsheet was developed for the F-Canyon dissolvers. The dissolvers are continually purged with nominally 33 SCFM of air; therefore the generation of flammable gas concentrations should not be a concern. Following removal of crucible fragments, small batches of the remaining sand fines or slag chunks containing less than approximately 350 grams of plutonium can be dissolved using the center insert in each of the four annular dissolver ports to address nuclear criticality safety concerns.

Complete dissolution of the sand fines and slag chunks was achieved in laboratory experiments by heating between 75 and $85^{\circ} \mathrm{C}$ in a $9.3 \mathrm{M}$ nitric acid / $0.013 \mathrm{M}$ (hydrogen) fluoride solution. Under these conditions, the sand and slag samples dissolved between 1 and 3 hours. Complete dissolution of plutonium and calcium fluorides in the slag required adjusting the dissolver solution to $7.5 \mathrm{wt} \%$ aluminum nitrate nonahydrate (ANN). Once ANN was added to a dissolver solution, further dissolution of any plutonium oxide $\left(\mathrm{PuO}_{2}\right)$ in successive charges was not practical due to complexation of the fluoride by aluminum. During the laboratory experiments, well mixed solutions were necessary to achieve rapid dissolution rates. When agitation was not provided, sand fines dissolved very slowly. Measurement of the hydrogen gas generation rate during dissolution of slag samples was used to estimate the amount of metal in the chunks. Depending upon the yield of the reduction, the values ranged between approximately 1 (good yield) and $20 \%$ (poor yield). Aging of the slag will reduce the potential for hydrogen generation as calcium metal oxidizes over time.

The potential for excessive corrosion in the dissolvers was evaluated using experimental data reported in the literature. Corrosion data at the exact flowsheet conditions were not available; however, the corrosion rate for $304 \mathrm{~L}$ stainless steel (wrought material) corrosion coupons in $10 \mathrm{M}$ nitric acid $/ 0.01 \mathrm{M}$ hydrofluoric acid at $95^{\circ} \mathrm{C}$ was reported as 21 mils per year. If the fluoride in the dissolver is complexed with aluminum, the corrosion rate will decrease to approximately 5 mils per year. 
the FB-Line dissolver for SS\&C processing is precluded due to concerns with the generation of flammable hydrogen gas from the reaction of unreacted calcium in the slag with the nitric acid solution. Dilution of potential hydrogen concentrations to less than one fourth of the lower flammability limit ( $1 \mathrm{vol} \%$ ) cannot be accomplished with the present equipment configuration.

To address the hydrogen generation from residual calcium metal in SS\&C, the use of an F-Canyon dissolver was proposed. Small batches containing less than approximately 350 grams of plutonium were proposed for dissolution in each of the four annular dissolver ports. The dissolvers are continually purged with nominally 33 SCFM of air. The generation of flammable concentrations of hydrogen should not be of concern (but, was investigated as part of this study). In contrast with the FB-Line dissolver, the canyon flowsheet must be designed to completely dissolve all of the solids charged to the dissolver to alleviate any nuclear safety concerns. With the FB-Line flowsheet, undissolved $\mathrm{CaF}_{2}$ was normally found in the dissolver and, therefore, its elimination was a primary objective of the development program.

\section{Experimental}

Samples of SRS and Rocky Flats SS\&C were obtained from the inventory of material currently stored at the site. Samples of sand fines and slag chucks were removed from the containers, weighed, repackaged, and assayed before shipment to the Savannah River Technology Center for dissolution studies. Crucible parts were not included as part of the samples. After the bulk weights were obtained, the sand and slag samples were nondestructively assayed for total plutonium content for comparison with values achieved during the dissolution studies.

\section{Dissolution Studies}

Dissolution experiments were performed by charging the laboratory dissolver (beaker) with the selected solutions of nitric acid, hydrogen fluoride, and ANN. The dissolver solution and sand or slag were added to the beaker at selected solids to liquid ratios. The beaker was placed on a hot plate and heated to the desired temperature using a stainless steel dial thermometer for indication and manually controlling the hot plate temperature. The solids dissolution time was then recorded as a function of dissolver solution concentrations, solids to liquid ratio, and temperature. In each experiment, the goal was to completely dissolve all of the solids; although, initially, complete dissolution was not obtained in several experiments.

\section{Hydrogen Generation}

The hydrogen evolution from sand fines and slag chucks was measured by reacting samples of each material with $10 \mathrm{ml}$ of $12.4 \mathrm{M}$ nitric acid / $0.14 \mathrm{M}$ ANN in a closed system for gas collection. Following a brief (1-2 minute) but vigorous reaction period, gas samples were analyzed specifically for hydrogen using gas chromatography. 


\section{Discussion}

\section{SS\&C Dissolution Flowsheet}

The primary objective of the dissolution studies was to identify flowsheet conditions for complete dissolution of all solids. Laboratory experiments were completed with separate batches of sand fines and slag chunks. Solids at different mass to volume ratios were added to nitric acid solutions containing low fluoride concentrations. ANN was added as a complexant to facilitate the complete dissolution of calcium and plutonium fluorides associated with the slag. Optimization of the flowsheet conditions was performed by fixing the solids to liquid ratio while adjusting the concentrations of nitric acid, (hydrogen) fluoride, ANN, and temperature and noting the time required for complete dissolution, if achieved. The time required for complete dissolution was based on visual observation. A record of the flowsheet conditions and resulting dissolution times is given in Table 1 .

Initially, very aggressive conditions (high concentrations of nitric acid/fluoride at the solution boiling point) were used in the dissolution experiments. Gradually the concentrations of acid/fluoride and temperature were reduced during the studies while maintaining the dissolution times in the 1 to 3 hour time frame. The optimum concentrations identified for the dissolver solution are $9.3 \mathrm{M}$ nitric acid and $0.013 \mathrm{M}$ (hydrogen) fluoride. The dissolver solution should be maintained between 75 and $85^{\circ} \mathrm{C}$ during the dissolution. Under these conditions, the sand fines and slag chunks should dissolve in 1 to 3 hours; although, the dissolution of the slag chunks could potentially required longer dissolution times if large chunks (greater than approximately $1 / 2$-inch in diameter) are dissolved. Complete dissolution of plutonium and calcium fluorides required adjusting the dissolver solution to $7.5 \mathrm{wt} \%$ ANN. Solid to liquid ratios in the laboratory experiments were varied between approximately 1 and 23 . The effect of changes in this range could not be quantified from the available data. For a canyon flowsheet, a value in the 4 to 6 range should be adequate to ensure a good dissolution rate and not exceed the solubility limit of $\mathrm{CaF}_{2}$. During initial scouting experiments, it was also observed that well mixed solutions were necessary to achieve rapid dissolution rates. When agitation was not provided, sand fines dissolved unacceptably slow.

Only small amount of plutonium can be charged to the dissolvers due to nuclear criticality safety constraints; therefore, efficient operations dictate that multiple batches of material be charged sequentially to a dissolver (following dissolution of most solids in the previous batch) until the plutonium concentration approaches the operating constraint. Since ANN must be added to a dissolver as a complexant to facilitate the complete dissolution of calcium and plutonium fluorides in the slag, the charging of slag should be the last batch charged to a dissolver. Following the ANN addition, further dissolution of $\mathrm{PuO}_{2}$ in sand fines would be prohibitively difficult. 
As a result of the laboratory dissolution studies, the composition of both SRS and Rocky Flats sand fines and slag chunks were characterized. The nominal composition ranges for each material are given in Table 2. Multiple measurements of the plutonium concentration in sand and slag samples from a series of ten cans of SRS and Rocky Flats SS\&C are shown in Table 3. The table also lists the overall assay for the 10 cans. In a few cases, the plutonium concentration of the discrete samples of sand and slag taken from these cans is close to the can assay which does show uniformity in composition; however, the data in both Tables 2 and 3 generally illustrate that the concentrations of plutonium and other sand and slag components were highly variable. Generalizations concerning the compositions are given below.

1. The plutonium concentration in the SRS sand fines was 4 to 5 times higher than the concentration in the slag chunks. The plutonium enrichment in the Rocky Flats fines was even more pronounced.

2. Little unreacted calcium was found in the either the SRS or Rocky Flats sand fines. Most of the unreacted calcium was found in the slag chucks where the fused salt prevented oxidation.

3. The $\mathrm{CaO}$ concentration in the sand fines was approximately a factor of two higher than the concentration of the $\mathrm{CaF}_{2} ; \mathrm{CaF}_{2}$ was the most prevalent species in the slag.

\section{Hydrogen Generation}

The volume of gas and concentration of hydrogen generated by the dissolution of sand and slag samples from 8 cans of SS\&C material are shown in Table 4. Following correction of the gas volume to standard conditions ( $273 \mathrm{~K}$ and $1 \mathrm{~atm}$ ), the concentration was used to calculate the volume of hydrogen per gram of sample (see Table 4). This value was then used to calculate the concentration of calcium metal in the sample.

During the dissolution process, the reaction of calcium metal with water generates only hydrogen gas as illustrated by equation (5).

$$
\mathrm{Ca}+2 \mathrm{H}_{2} \mathrm{O} \rightarrow \mathrm{Ca}(\mathrm{OH})_{2}+\mathrm{H}_{2}
$$

However, calcium will also react with the nitric acid in the dissolver solution by equations (6) and (7).

$$
\begin{aligned}
& 3 \mathrm{Ca}+8 \mathrm{H}^{+}+2 \mathrm{NO}_{3}^{-} \rightarrow 2 \mathrm{NO}+4 \mathrm{H}_{2} \mathrm{O}+3 \mathrm{Ca}^{2+} \\
& 4 \mathrm{Ca}+10 \mathrm{H}^{+}+2 \mathrm{NO}_{3}^{-} \rightarrow \mathrm{N}_{2} \mathrm{O}+5 \mathrm{H}_{2} \mathrm{O}+4 \mathrm{Ca}^{2+}
\end{aligned}
$$

Based on experimental data, approximately $45 \%$ of the calcium reacts with water (by equation (5)) to produce hydrogen. Therefore, the mass of calcium in the slag and sand fines can was calculated from the volume of gas and then corrected to account for the reaction of calcium by equations (6) and (7). This concentration is reported in Table 4 for each of the samples. From the data in Table 4, it is apparent that the majority of calcium metal is in the slag chunks. This observation is consistent with the fact that calcium metal readily oxidizes when exposed to air as 
would be the case in the sand fines. The majority of the calcium metal should be found in the fused slag where it is protected from oxidation. The disproportionately high value of calcium reported for sample 95002-1 is due to the fact that slag chunks were ground to produce the sand fines.

The amount of calcium in the sand and slag should be inversely proportional to the reduction yield assuming the decrease in yield is not due to oxidation of the calcium metal prior to the reaction. There will always be excess metal following reaction due to the $30 \%$ excess calcium which is typically used during the reduction process. The unreacted calcium metal from slag samples 530-1, 420-1, and SC178-1 listed in Table 4 are typical of good, fair, and poor reduction yields, respectively. The concentration of metal in the samples increases from good to poor reduction yield as one would expect. It should also be noted that the quantity of calcium metal in the sand and slag should decrease with time as the metal oxidizes. This is especially true for the sand fines, where the metal is more accessible and subject to more rapid oxidation.

\section{Dissolver Corrosion}

The potential for excessive corrosion rates in the canyon dissolvers was evaluated based on experimental data reported in the literature. ${ }^{1,2}$ Corrosion data at the exact flowsheet conditions were not available; however, the corrosion rate for 304L stainless steel (wrought material) corrosion coupons in $10 \mathrm{M}$ nitric acid/0.01M hydrofluoric acid at $95^{\circ} \mathrm{C}$ was reported as $21 \mathrm{mils}$ per year. An increase in temperature would result in an increase in the corrosion rate. A corrosion rate greater than 50 mils per year for 304L stainless steel has been reported for boiling temperatures in a $6 \mathrm{M}$ nitric acid/0.01M hydrofluoric acid solution. ${ }^{1}$ Therefore, the corrosion rate of steam coils in the dissolver is expected to have the highest corrosion rate. There is also evidence that the presence of corrosion products such as iron and dichromate $\left(\mathrm{Cr}_{2} \mathrm{O}_{7}{ }^{2-}\right)$ can also adversely affect the corrosion rate of 304L stainless steel in nitric acid. These corrosion products are second to uncomplexed fluoride in aggressiveness because they increase intergranular attack autocatalytically.

Increases in the hydrofluoric acid would also significantly increase the corrosion rate. For example, an increase of the hydrofluoric acid concentration from 0.01 to $0.1 \mathrm{M}$ in $10 \mathrm{M}$ nitric acid at $95^{\circ} \mathrm{C}$ would increase the corrosion rate from 21 to 248 mils per year. Similarly, decreases in the hydrofluoric acid concentration will reduce the corrosion rate. For comparison purposes, the corrosion rate of $304 \mathrm{~L}$ stainless steel in $9 \mathrm{M}$ nitric acid at $85-95^{\circ} \mathrm{C}$ is less than 5 mils per year. ${ }^{3}$ If the fluoride in the dissolver is complexed with aluminum, the corrosion rate decreases significantly. The corrosion rate of $304 \mathrm{~L}$ stainless steel in $10 \mathrm{M}$ nitric acid/0.1M hydrofluoric acid/0.3M aluminum nitrate at $95^{\circ} \mathrm{C}$ is approximately 7 mils per year. 


\section{Conclusions}

Complete dissolution of sand fines and slag chunks generated during the calcium reduction of plutonium fluoride/oxide mixtures was achieved by heating between 75 and $85^{\circ} \mathrm{C}$ in a $9.3 \mathrm{M}$ nitric acid / 0.013M (hydrogen) fluoride solution. Under these conditions, the sand and slag samples dissolved between 1 and 3 hours. Complete dissolution of plutonium and calcium fluorides in the slag required adjusting the dissolver solution to $7.5 \mathrm{wt} \% \mathrm{ANN}$. If successive batches of SS\&C material are dissolved, the charging of slag chunks should be performed last due to the addition of ANN. Once ANN has been added to the dissolver solution, further dissolution of $\mathrm{PuO}_{2}$ will be extremely slow due to complexation of the fluoride by aluminum. The effect of changes in the solid to liquid ratio on the dissolution time could not be quantified with the available data; however, a value in the 4 to 6 range should be adequate to ensure a good dissolution rate in the canyon dissolvers and prevent the $\mathrm{CaF}_{2}$ concentration from exceeding the solubility limit. During the laboratory experiments, well mixed solutions were necessary to achieve rapid dissolution rates. When agitation was not provided, sand fines dissolved very slowly.

The composition of the sand and slag samples used to develop the dissolution flowsheet varied widely. The concentration of plutonium in the sand fines was at least a factor of 4 to 5 times higher than the concentration in the slag chunks. Little unreacted calcium metal was found in the sand fines. Most of the calcium was found in the slag chunks where the fused salt prevented oxidation. Measurement of the hydrogen gas generation rate during dissolution of slag samples was used to estimate the amount of metal in the chunks. Depending upon the yield of the reduction, the values ranges between approximately 1 (good yield) and $20 \%$ (poor yield). Aging of the slag will reduce the potential for hydrogen generation as calcium metal oxidizes over time.

The potential for excessive corrosion in the canyon dissolvers was evaluated using experimental data reported in the literature. Corrosion data at the exact flowsheet conditions were not available; however, the corrosion rate for 304L stainless steel (wrought material) corrosion coupons in $10 \mathrm{M}$ nitric acid/ $0.01 \mathrm{M}$ hydrofluoric acid at $95^{\circ} \mathrm{C}$ was reported as 21 mils per year. If the fluoride in the dissolver is complexed with aluminum, the corrosion rate decreases significantly. The addition of $0.3 \mathrm{M}$ ANN to a solution of $10 \mathrm{M}$ nitric acid/ $0.1 \mathrm{M}$ hydrofluoric acid at $95^{\circ} \mathrm{C}$, reduces the $304 \mathrm{~L}$ stainless steel corrosion rate from 248 to approximately 7 mils per year. 


\section{References}

1. P. M. Kranzlein, "Corrosion of Steel in $\mathrm{HNO}_{3}$ - HF Solutions, “ External Report DP-486, E. I. du Pont de Nemours and Co., Aiken, SC (July 1960).

2. R. S. Ondrejcin and B. D. McLaughlin, "Corrosion of High Ni-Cr Alloys and Type 304L Stainless Steel in $\mathrm{HNO}_{3}-\mathrm{HF}$, " External Report DP 1550, E. I. du Pont de Nemours and Co., Aiken, SC (April 1980).

3. "Handbook of Corrosion Data, "ASM International: Metals Park, OH (1989). 
Table 1 Dissolution Times for Sand and Slag Residues

\begin{tabular}{|c|c|c|c|c|c|c|c|}
\hline $\begin{array}{c}\text { Residue } \\
\text { ID }\end{array}$ & $\begin{array}{c}\text { Solids to } \\
\text { Liquid } \\
\text { Ratio } \\
\text { (g/l) }\end{array}$ & $\begin{array}{c}\text { Nitric } \\
\text { Acid } \\
\text { Conc. } \\
\text { (moles } / 1 \text { ) }\end{array}$ & $\begin{array}{l}\text { ANN } \\
\text { Conc. } \\
(w t \%)\end{array}$ & $\begin{array}{l}\text { Fluoride } \\
\text { Conc } \\
\text { (moles } / \text { l) }\end{array}$ & Temp. & $\begin{array}{c}\text { Solids } \\
\text { Dissolved }\end{array}$ & $\begin{array}{c}\text { Dissol. } \\
\text { Time } \\
\text { (min) }\end{array}$ \\
\hline SRS Sand & 1.3 & 14.1 & 0.0 & 0.010 & boiling & all & 15 \\
\hline SRS Sand & 2.7 & 14.1 & 0.0 & 0.010 & boiling & all & 44 \\
\hline SRS Sand & 5.3 & 14.1 & 0.0 & 0.010 & boiling & all & 19 \\
\hline SRS Sand & 7.8 & 14.1 & 0.0 & 0.010 & boiling & all & 40 \\
\hline SRS Sand & 12.8 & 14.1 & 0.0 & N/A & boiling & partial & 85 \\
\hline SRS Sand & 6.4 & 14.1 & 15.0 & N/A & boiling & all & 45 \\
\hline SRS Sand & 2.1 & 14.1 & 15.0 & 0.010 & boiling & partial & 90 \\
\hline SRS Sand & 9.2 & 14.1 & 0.0 & N/A & boiling & partial & 85 \\
\hline RF Sand & 1.6 & 10.5 & 0.0 & 0.015 & 85 & all & 16 \\
\hline RF Sand & 2.9 & 10.5 & 0.0 & 0.015 & 85 & all & 12 \\
\hline RF Slag & 6.0 & 10.5 & 0.0 & N/A & 85 & partial & 75 \\
\hline RF Slag & 3.0 & 8.0 & 15.0 & N/A & boiling & all & 40 \\
\hline SRS Sand & 3.4 & 10.5 & 0.0 & 0.015 & 85 & all & 30 \\
\hline SRS Slag & 8.8 & 10.5 & 0.0 & N/A & boiling & partial & 120 \\
\hline SRS Slag & 5.4 & 8.0 & 15.0 & N/A & boiling & all & 60 \\
\hline SRS Sand & 1.4 & 7.0 & 0.0 & 0.015 & 85 & all & 46 \\
\hline SRS Slag & 23.0 & 7.0 & 0.0 & N/A & 85 & partial & 67 \\
\hline SRS Slag & 12.0 & 7.0 & 7.5 & N/A & 85 & all & 17 \\
\hline RF Sand & 2.1 & 10.1 & 0.0 & 0.015 & 85 & all & 9 \\
\hline RF Sand & 4.3 & 10.1 & 0.0 & 0.015 & boiling & all & 40 \\
\hline RF Sand & 3.5 & 9.3 & 0.0 & 0.010 & 85 & all & 16 \\
\hline RF Slag & 2.5 & 9.3 & 7.5 & $N / A$ & 85 & all & 62 \\
\hline RF Sand & 1.5 & 9.3 & 0.0 & 0.013 & 85 & all & 94 \\
\hline RF Sand & 3.6 & 9.3 & 0.0 & 0.013 & 76 & all & 115 \\
\hline RF Sand & 5.2 & 9.3 & 0.0 & 0.013 & 65 & partial & 148 \\
\hline RF Slag & 6.7 & 9.3 & 0.0 & $N / A$ & 84 & partial & 120 \\
\hline RF Slag & 5.1 & 9.3 & 7.5 & N/A & 84 & all & 180 \\
\hline SRS Sand & 1.5 & 9.3 & 0.0 & 0.013 & 81 & all & 120 \\
\hline SRS Sand & 2.4 & 9.3 & 0.0 & 0.013 & 78 & all & 60 \\
\hline SRS Slag & 2.7 & 9.3 & 7.5 & N/A & 82 & all & 72 \\
\hline SRS Slag & 5.2 & 9.3 & 7.5 & N/A & 81 & all & 61 \\
\hline SRS Sand & 1.4 & 9.3 & 0.0 & 0.013 & 71 & all & 86 \\
\hline SRS Sand & 2.9 & 9.3 & 0.0 & 0.013 & 71 & all & 141 \\
\hline SRS Slag & 9.6 & 9.3 & 15.0 & N/A & 71 & all & 183 \\
\hline
\end{tabular}


WSRC-TR-97-00367

Revision 0

Table 2 Nominal Composition of Sand and Slag Residues

\begin{tabular}{ccc}
\hline \hline Component & $\begin{array}{c}\text { Sand Composition } \\
(\text { wt } \%)\end{array}$ & $\begin{array}{c}\text { Slag Composition } \\
(\text { wt } \%)\end{array}$ \\
\hline $\mathrm{Pu}$ (SRS) & $12-56$ & $3-10$ \\
$\mathrm{Ca}$ (SRS) & $0-2$ & $1-20$ \\
$\mathrm{Pu}$ (Rocky Flats) & $25-54$ & $1-8$ \\
$\mathrm{Ca}$ (Rocky Flats) & $0-1$ & $0-5$ \\
$\mathrm{CaO}$ & $30-50$ & $5-10$ \\
$\mathrm{CaF}$ & $10-30$ & $60-80$ \\
$\mathrm{MgO}$ & $5-15$ & $1-5$ \\
\hline
\end{tabular}


WSRC-TR-97-00367

Revision 0

Table 3 Measured Plutonium Concentrations in Sand and Slag Residues

\begin{tabular}{cccc}
\hline \hline $\begin{array}{c}\text { Can } \\
\text { Designation }\end{array}$ & $\begin{array}{c}\text { Plutonium Assay } \\
\text { for Total Can } \\
(\mathrm{wt} \%)\end{array}$ & $\begin{array}{c}\text { Residue } \\
\text { Component }\end{array}$ & $\begin{array}{c}\text { Plutonium } \\
\text { Concentrations } \\
(\mathrm{wt} \%)\end{array}$ \\
\hline SC420-1 & 20 & SRS Fines & $54,23,56$ \\
SC178 & 25 & SRS Slag & $9.5,3.2$ \\
& & SRS Fines & 28,30 \\
95002-1 & 4.4 & SRS Slag & 4.0 \\
& & SRS Fines & 4.3 \\
$530-1$ & 10 & SRS Slag & $2.7,7.1$ \\
& & SRS Fines & $13,12,14$ \\
RF04625 & 24 & SRS Slag & 5.8 \\
& & RF Fines & 36 \\
SRP27-1 & 11 & RF Slag & $4.9,1.2$ \\
& & RF Slag & 7.6 \\
$1802 B$ & 20 & RF Fines & 31 \\
& & RF Slag & $5.4,2.6$ \\
$4619 A$ & & RF Fines & 54,29 \\
& \multirow{2}{*}{20} & RF Slag & $3.8,3.7$ \\
1793B & & RF Fines & 46,35 \\
& & RF Slag & 2.0 \\
SRP29-1 & \multirow{2}{*}{15} & RF Fines & 24 \\
& & & $3.1,0.6$ \\
\hline
\end{tabular}


WSRC-TR-97-00367

Revision 0

Table 4 Hydrogen Generation from Sand Fines and Slag Chunks

\begin{tabular}{|c|c|c|c|c|c|c|}
\hline Sample & $\begin{array}{c}\text { Sample } \\
\text { Mass } \\
(\mathrm{g})\end{array}$ & $\begin{array}{c}\text { Volume } \\
\text { Gas } \\
(\mathrm{ml})\end{array}$ & $\begin{array}{c}\text { Volume } \\
\text { Gas (STP) } \\
(\mathrm{ml})\end{array}$ & $\begin{array}{l}\text { Hydrogen } \\
\text { Conc } \\
(\%)\end{array}$ & $\begin{array}{c}\mathrm{ml} \mathrm{H}_{2} \text { per } \\
\text { g sample } \\
(\mathrm{ml} / \mathrm{g})\end{array}$ & $\begin{array}{c}\text { mg Ca per } \\
\text { g sample } \\
(\mathrm{mg} / \mathrm{g})\end{array}$ \\
\hline $420-1^{(2)}$ & 4.826 & 92 & 84.3 & $9.5 \pm 0.6$ & 1.7 & 6.6 \\
\hline $420-1 C^{(2)}$ & 4.162 & est 200 & 184 & $20.8 \pm 0.15$ & 9.2 & 37 \\
\hline $530-1^{(1)}$ & 8.950 & 120 & 110.4 & $1.04 \pm 0.07$ & 0.1 & 0.5 \\
\hline $530-1 C^{(1)}$ & 7.467 & 204 & 187.6 & $14.3 \pm 0.9$ & 3.6 & 14 \\
\hline $95002-1^{(4)}$ & 5.404 & 280 & 257 & 27 & 12.8 & 51 \\
\hline $95002-1 \mathrm{C}$ & 3.780 & est 430 & 394 & 46 & 47.9 & 191 \\
\hline $\mathrm{SC} 178-1^{(3)}$ & 2.046 & 10 & 9 & $<0.25$ & $<0.01$ & $<0.04$ \\
\hline$S C 178-1 C^{(3)}$ & 2.654 & 230 & 211 & 36 & 28.6 & 114 \\
\hline SRP-27-1 & 7.132 & 222 & 204 & 0.79 & 0.2 & 0.9 \\
\hline SRP-27-1C & 6.372 & 0 & 0 & 0 & 0 & 0 \\
\hline 1802B & 5.706 & 206 & 189 & 0.21 & 0.1 & 0.3 \\
\hline $1802 \mathrm{BC}$ & 2.378 & 0 & 0 & 0 & 0 & 0 \\
\hline SRP 29-1 & 4.070 & 196 & 178 & 1.90 & 0.8 & 3.3 \\
\hline SRP 29-1C & 4.083 & 150 & 137 & 34.0 & 11.4 & 45 \\
\hline 1793-B & 5.273 & 120 & 109 & 4.45 & 0.9 & 3.7 \\
\hline $1793-\mathrm{BC}$ & 1.510 & 50 & 46 & 8.22 & 2.5 & 10 \\
\hline
\end{tabular}

(1) high reduction yield

(2) fair reduction yield

(3) poor reduction yield

(4) sand fines produced by grinding slag chunks

$\mathrm{C}$ designates slag chunks

est - estimated volume 